\title{
Isolasi dan Identifikasi Bakteri Resisten Merkuri pada Plak Gigi dan Urin
}

\author{
${ }^{1}$ Priscilla Lumanto \\ ${ }^{2}$ Aaltje Manampiring \\ ${ }^{2}$ Fona Budiarso
}

\author{
${ }^{1}$ Program Studi Pendidikan Dokter Fakultas Kedokteran Universitas Sam Ratulangi Manado \\ ${ }^{2}$ Bagian Kimia Fakultas Kedokteran Universitas Sam Ratulangi Manado \\ Email: lumantosela@yahoo.com
}

\begin{abstract}
Mercury toxic effects could be reduced by the presence of mercury resistant microorganisms, such as mercury resistant bacteria. These bacteria possess mercury resistant gene, the operon mere gene. Resistance could also occur through genes that code mercury resistant characteristics and of other heavy metal compounds that generally located within the plasmid. This study was aimed to obtain the profile of bacteria in dental plaque and urine that were resistant to mercury. This was a descriptive prospective study with a cross-sectional design. Isolation and identification of the bacteria were conducted at Microbiology Laboratory of Pharmacy Department, Sam Ratulangi University. The results obtained bacteria of Bacillus $s p$. which were sensitive to antibiotics ciprofloxacin, erythromycin, and doxycyclin. Conclusion: Mercury resistent bacteria in dental plaque and urine were sensitive to antibiotics ciprofloxacin, erythromycin, and doxycyclin.
\end{abstract}

Keywords: mercury resistent bacteria, dental plaque, urine

\begin{abstract}
Abstrak: Toksisitas merkuri dapat berkurang oleh adanya mikroorganisme resisten merkuri, misalnya bakteri resisten merkuri. Hal ini terjadi karena bakteri memiliki gen yang resisten terhadap merkuri, yaitu gen operon mer. Resistensi juga dapat melalui gen yang mengkode sifat resisten terhadap merkuri dan senyawa logam berat lainnya yang umumnya terletak pada plasmid. Penelitian ini bertujuan untuk mengetahui gambaran bakteri dari plak gigi dan urin yang resistensi terhadap merkuri. Jenis penelitian ialah deskriptif prospektif dengan desain potong lintang. Isolasi dan identifikasi bakteri dari plak gigi dan urin yang resisten terhadap merkuri dilakukan di Laboratorium Mikrobiologi Farmasi FMIPA Unsrat. Hasil penelitian mendapatkan bakteri dari sampel gigi dan urine ialah bakteri Bacillus sp. yang sensitif terhadap antibiotik siprofloksasin, eritromisin, dan doksisiklin. Simpulan: Bakteri resisten terhadap merkuri dalam sampel plak gigi dan urin ialah Bacillus sp. yang sensitif terhadap antibiotik siprofloksasin, eritromisin, dan doksisiklin.
\end{abstract}

Kata kunci: bakteri resisten merkuri, plak gigi, urin

Logam memiliki peranan penting dalam kehidupan manusia, namun baik secara langsung maupun tidak langsung, sengaja maupun tidak sengaja telah mencemari lingkungan. Logam berat seperti potasium, sodium, kalsium, dan tembaga dianggap penting untuk beberapa keperluan. Beberapa logam berat lainnya tidak memiliki fungsi penting bahkan sebaliknya memiliki efek toksik terhadap sel, seperti merkuri
$(\mathrm{Hg})$, kadmium $(\mathrm{Cd})$, timbal $(\mathrm{Pb})$, kromium $(\mathrm{Cr})$, nikel (Ni), dan arsen (As). Logamlogam tersebut dapat terakumulasi di dalam tubuh suatu organisme dan tinggal menetap dalam jangka waktu lama sebagai racun terakumulasi. $^{1,2}$

Penggunaan logam merkuri pada kegiatan perindustrian maupun laboratorium karena logam merkuri merupakan salah satu trace element yang mempunyai 
sifat cair pada suhu ruang dengan gravitasi spesifik dan daya hantar listrik yang tinggi. ${ }^{3}$ Dalam kehidupan sehari-hari, seperti pada praktik dokter gigi, merkuri paling umum digunakan sebagai bahan tumpatan yang biasa disebut amalgam. ${ }^{4}$

Merkuri memiliki sifat toksik yang dapat berkurang oleh adanya mikroorganisme resisten merkuri, misalnya bakteri resisten merkuri. Hal ini dapat terjadi karena bakteri memiliki gen yang resisten terhadap merkuri, yaitu gen operon mer. Dengan adanya gen operon mer ini, bakteri mampu mereduksi ion $\mathrm{Hg}^{2+}$ menjadi $\mathrm{Hg}^{0}$ yang sebelumnya bersifat toksik menjadi kurang toksik. ${ }^{5}$ Resistensi juga dapat melalui gen yang mengkode sifat resisten terhadap merkuri dan senyawa logam berat lainnya yang umumnya terletak pada plasmid yang sama sehingga suatu bakteri dapat menunjukkan sifat resisten terhadap logam berat dan antibiotik secara bersamasama. $^{6}$

Penelitian yang dilakukan oleh Rehman dan Ali melaporkan bahwa bakteri Pseudomonas sp. merupakan salah satu bakteri yang telah resisten terhadap merkuri. $^{7}$ Penelitian yang dilakukan oleh Palilingan et al. ${ }^{8}$ menunjukkan bahwa bakteri Pseudomonas sp. yang diisolasi dari plak gigi pasien yang menggunakan tumpatan amalgam telah resisten terhadap merkuri dan juga antibiotik amoksisilin.
Christi et al. ${ }^{7}$ mendapatkan bakteri yang teridentifikasi dan resisten terhadap merkuri dari plak gigi pasien di Tikala Baru Manado ialah bakteri Staphylococcus sp., Brucella sp. dan Phenylobacterium sp. Penelitian Bahter et al. ${ }^{9}$ memperlihatkan bahwa dalam sampel urin pasien dengan tumpatan amalgam merkuri di Poli Gigi Puskesmas Tuminting terdapat bakteri resisten merkuri yaitu Bacillus $s p$, Staphylococcus sp, Klebsiella sp, Hafnia $s p$, Eschericia sp, dan Enterobacter sp.

\section{METODE PENELITIAN}

Penelitian ini bertujuan untuk mendapatkan gambaran bakteri dari plak gigi dan urin yang resisten terhadap merkuri. Jenis penelitian ini ialah deskriptif prospektif dengan desain potong lintan untuk mendapatkan gambaran bakteri dari plak gigi dan urin yang resisten terhadap merkuri. Penelitian dilaksanakan pada bulan September sampai dengan November 2017. Isolasi dan identifikasi bakteri dari plak gigi dan urin yang resisten terhadap merkuri dilakukan di Laboratorium Mikrobiologi Farmasi FMIPA Unsrat.

\section{HASIL PENELITIAN}

Pengumpulan sampel yang dilaksanakan dari bulan September sampai dengan November 2017 mendapatkan hasil sebagai berikut:

Tabel 1. Hasil isolasi dan identifikasi bakteri dari sampel gigi dan urin

\begin{tabular}{llccc}
\hline No. & \multicolumn{3}{c}{ Nama uji } & \multicolumn{3}{c}{ Kode isolat } \\
\cline { 3 - 5 } & & $\mathbf{G 4 0 . 2}$ & $\mathbf{A 4 0 . 4}$ & VR.40 \\
\hline 1 & Motilitas & - & + & - \\
2 & Indol & - & - & - \\
3 & Citrat & + & + & + \\
4 & Katalase & + & + & + \\
5 & H2S & - & + & - \\
6 & Methyl Red & + & + & + \\
7 & Voges Proskauer & - & - & - \\
8 & Pewarnaan Gram & Bacill (+) & Bacill (+) & Bacill (+) \\
9 & Hasil & Bacillus sp & Bacillus sp & Bacillus sp \\
\hline
\end{tabular}

Keterangan: G40.2: isolat dari Gigi, A40.4 dan VR.40: isolat dari Urine 


\section{BAHASAN}

Bakteri merupakan mikroorganisme yang memiliki sifat sebagai unisel prokariot, di mana hanya dapat diamati dengan menggunakan alat bantu, yaitu mikroskop. Bakteri bersifat sel tunggal, dengan ukuran rata-rata 0,5 sampai beberapa mikron, dapat hidup secara sendiri-sendiri (soliter) atau berkelompok (koloni). Bakteri dapat berkembang biak dengan membelah diri dan bahan-bahan genetiknya tidak terbungkus dalam membran inti. Bakteri memiliki beberapa jenis bentuk seperti basil, kokus, spiral, dan vibrio. ${ }^{10,11}$

Umumnya bakteri berkembang biak dengan memperbanyak diri, yaitu dengan cara pembelahan sel. Perkembangan bakteri harus dalam suasana dan lingkungan yang cukup baik, misalnya dalam media pembenihan, maka bakteri dapat memperbanyak diri dengan cepat. Faktor-faktor suasana dan lingkungan yang mendukung dan memengaruhi pertumbuhan atau perkembangan bakteri, antara lain nutrien, suhu, $\mathrm{pH}$, dan aerasi harus dicermati dengan baik. Lingkungan nutrien yang mendukung akan merangsang perkembangan bakteri dengan baik. Sebagian besar organisme tumbuh paling baik pada $\mathrm{pH} 6,0-8,0$, meskipun beberapa memiliki $\mathrm{pH}$ optimal serendah 3,0 dan ada yang memiliki $\mathrm{pH}$ normal setinggi 10,5. Suhu juga memengaruhi perkembangan bakteri. Spesies mikroba yang berbeda memiliki kisaran suhu optimal untuk pertumbuhan yang sangat beragam. Suhu yang rendah dapat menyebabkan aktivitas enzim menurun dan jika suhu terlalu tinggi dapat menyebabkan denaturasi protein enzim. Pada suhu optimum pertumbuhan bakteri berlangsung dengan cepat. Di luar kisaran suhu optimum pertumbuhan bakteri menjadi lambat atau bahkan tidak ada pertumbuhan. ${ }^{11}$

Bakteri dapat bertahan hidup dalam merkuri dan mampu melakukan detoksifikasi, karena bakteri resisten merkuri memiliki gen resisten merkuri, yaitu mer operon. Setiap bakteri resisten merkuri memiliki gen operon yang berbeda-beda. Struktur gen operon umumnya terdiri dari gen metaloregulator (meR), gen transpor merkuri (merT, merP, merC), gen merkuri reduktase (merA), dan organomerkuri liase (merB). ${ }^{1}$

Berdasarkan hasil penelitian yang diperoleh dengan mengambil sampel gigi dan urine pasien, maka ditemukan bakteri resisten merkuri pada kedua sampel dengan hasil uji resistensi merkuri menunjukkan hasil identifikasi semua isolat, yaitu bakteri Bacillus sp.

Bakteri genus Bacillus termasuk golongan kuman Bacillaceae dan merupakan bakteri berbentuk batang, memiliki spora (endospora) yang bersifat positif Gram dan bersifat aerob. Bacillus merupakan batang kecil dengan ukuran 0,3-2,2 $\mu \mathrm{m}$ x 1,2-7,0 $\mu \mathrm{m}$. Bakteri Bacillus sp. memiliki bentuk sel yang khas, yaitu mempunyai ujung persegi dan tersusun dalam rantai panjang; spora terletak di tengah-tengah basil non-motil. ${ }^{10-12}$ Bakteri Bacillus $s p$. memiliki spora yang resisten terhadap panas, radiasi, desinfektan dan pengeringan, sehingga sering sulit untuk menghilangkan bakteri Bacillus sp. dari bahan medis dan farmasi yang sering menyebabkan kontaminasi. Beberapa strain genus Bacillus laut dapat mendetoksifikasi logam berat melalui proses reduksi dan memiliki kemampuan menghasilkan karotenoid. ${ }^{13}$

Berdasarkan pedoman Clinical and Laboratorium Standard Institute (CLSI) diperoleh hasil semua bakteri yang diuji sensitivitas dengan antibiotik siprofloksasin, eritromisin, dan doksisiklin menunjukkan hasil yang masih sensitif. Hal ini menggambarkan bahwa bakteri Bacillus $s p$. masih sensitif terhadap ketiga antibiotik di atas. Kelompok kontrol menunjukkan hasil negatif, yaitu tidak membentuk zona hambat karena aquades tersebut tidak memiliki sifat antibakteri.

\section{SIMPULAN}

Dari hasil penelitian dapat disimpulkan bahwa bakteri resisten terhadap merkuri dalam sampel plak gigi dan urin ialah Bacillus sp. yang sensitif terhadap antibiotik siprofloksasin, eritromisin, dan doksisiklin. 


\section{SARAN}

Sebaiknya waktu penelitian lebih lama sehingga dapat dilakukan isolasi dan identifikasi bakteri yang lebih banyak dan uji sensitivitas menggunakan antibiotik yang lebih banyak sehingga dapat diketahui pola sensitivitas dan resistensi bakteri.

\section{DAFTAR PUSTAKA}

1. Osborn AM, Bruce KD, Strike P, Ritchie AD. Distribution, diversity and evolution of the bacterial mercury resistance (mer) operon. Federation of European Microbiological Societies. 1997;19(4):239-62. [cited 2016 August 16]. Available from: http:// www.ncbi.nlm.nih.gov/pubmed/91672 57

2. Fardiaz S. Polusi Air dan Udara (1st ed). Yogyakarta: Kanisius, 1992; p. 48-58.

3. Manampiring AE, Kepel BJ. Studi populasi bakteri resisten merkuri di daerah aliran sungai Tondano, Kelurahan Ketang Baru, Manado. Jurnal Ilmiah Sains. 2011;11(1):26-30.

4. Putranto TR. Pencemaran logam berat merkuri $(\mathrm{Hg})$ pada air tanah. Teknik. 2011;32(2):62-72.

5. Nofiani R, Gusrizal. Bakteri resisten merkuri spektrum sempit dari daerah bekas penambangan emas tanpa izin (peti) Mandor Kalimantan Barat. Jurnal Natur Indonesia. 2004;6(2): 67-74.

6. Brooks GF, Carroll KC, Butel JS, Morse SA. Melnick \& Adelberg's Medical Microbiology $\left(24^{\text {th }}\right.$ ed). USA: Mc Graw-Hill Medical, 2007.
7. Christi RE, Fatimawali, Yudistira A. Identifikasi dan uji resistensi bakteri dari plak gigi pasien dengan tumpatan amalgam di Puskesmas Tikala Baru terhadap merkuri dan antibiotik golongan penisilin. Pharmacon. 2017;6(3):200-7.

8. Palilingan W, Kepel BJ, dan Fatimawali. Uji resistensi bakteri Pseudomonas Sp. yang Diisolasi dari Plak Gigi Terhadap Merkuri dan Antibiotik Amoksisilin. eBm. 2015;3(3):716-21.

9. Bahter JVF, Kepel BJ, Fatimawali. Isolasi bakteri resisten merkuri pada urin pasien dengan tumpatan amalgam di Puskesmas Tuminting. e-Bm. 2016;4(2):1-7.

10. Syahrurachman A, Chatim A, Soebandrio AWK, Karuniawati A, Santoso AUS, et al. Buku Ajar Mikrobiologi Kedokteran (Edisi Revisi). Jakarta: Binarupa Aksara, 2010.

11. Jawetz, Melnick \& Adelberg's Prinsip Diagnostik Mikrobiologi Klinik dalam Mikrobiologi Kedokteran. (25th ed). AlihBahasa: Nugroho AW, et al. Jakarta: EGC, 2010.

12. Holt JG, Krieg NR, Sneath PHA, Staley JT, Williams ST. Bergey's Manual of Determinative Bacteriology (9th ed). USA: Williams and Wilkins, 1994.

13. Mondol MAM, Shin JH, Islam TM. Diversity of secondary metabolites from marine bacillus species: chemistry and biological activity. Marine Drugs. 2013;11:2846-72. 